\title{
Evaluasi Sistem Penggajian pada CV Lisa Jaya Mandiri Jember
}

\author{
Arum Anggraini ${ }^{1}{ }^{*}$, Arik Susbiyani ${ }^{2}$, Ibna Kamelia Fiel Afroh ${ }^{3}$ \\ 1,2,3 Fakultas Ekonomi, Universitas Muhammadiyah Jember, Jawa Timur, Indonesia
}

\section{A R T I C L E I N F O}

Article history:

Received 19 August 2018

Received in revised form

16 September 2018

Accepted 15 October 2018

Available online 26

November 2018

Kata Kunci:

Sistem Gaji

Keywords:

Salaries Systems

\begin{abstract}
A B S T RAK
Sumber Daya Manusia adalah salah satu aset terpenting perusahaan, dalam menjalankan tugas nya karyawan membutuhkan timbal balik jasa yang berupa gaji karyawan. Tujuan penelitian ini adalah untuk mengevaluasi sistem penggajian pada CV. Lisa Jaya Mandiri Jember, hal ini dilakukan dalam rangka mengidentifikasi dan memberikan rekomendasi atas permasalahan kesalahaan pada saat pemberian potongan karyawan dan kesalahan input data gaji CV. Lisa Jaya Mandiri Jember. Jenis penelitian ini menggunakan deskriptif kualitatif. Data yang diperoleh dalam penelitian ini berdasarkan observasi, wawancara, dan dokumentasi. Sumber data yang diperoleh adalah dari jenis sumber data primer dan sekunder. Dari hasil penelitian, dapat disimpulkan bahwa Sistem Penggajian masih belum memadai dan efektif, dimana masih kurangnya fungsi pengendalian yang ditandai dengan sering terjadinya kesalahan pada saat pemberian potongan karyawan dan kesalahan input data gaji perusahaan. Sehingga dalam pelaporannya mengalami ketidak tepatan waktu dan harus dilakukan pengecekan ulang terhadap pencatatan data gaji karyawan. Sehingga, perlu adanya evaluasi dan perbaikan kembali terkait Sistem Penggajian.
\end{abstract}

\section{A B S T R A C T}

Human Rosource is one of important asset to be owned by company, employees in to finished the jobs needs a Salary. The purpose of this research is to evaluation the payroll system in order on the CV. Lisa Jaya Mandiri Jember, this matter to identification and giving recomandation for a problem of misunderstanding when giving employee deductions and data input errors salary CV. Lisa Jaya Mandiri Jember. Type of research used is descritive qualitative research method. The data used are primary data and secondary data be obtained is Observation, Interview, and Documentation. The result of research, that is concluded that Payroll System is still inadequate and effective, where the lack of control function is marked by frequent occurrence of errors at the time of giving employees deductions and errors input data salary companies. So that in its reporting experience of not timeliness and must be checked again to recording salary data and employe. So, needs a evaluation and repairly about Payroll System.

\footnotetext{
* Corresponding author.

E-mail addresses: anggrainiarum27@gmail.com (Arum Anggraini)
} 


\section{Pendahuluan}

Keberadaan sebuah perusahaan sangat dipengaruhi oleh sistem yang berjalan dalam perusahan tersebut. Sebuah sistem yang baik menjadi kebutuhan penting bagi sebuah perusahaan. Sistem yang baik, tentu mampu mendukung segala aktivitas yang dijalankan perusahaan dalam mengembangkan bisnisnya. Bukan hanya memiliki sistem yang baik, perusahaan juga harus mampu berinovasi dan dapat bersaing kompetitif dengan perusahaan lainnya.

Sebuah perusahaan dalam mengembangkan kemampuannya tentu harus diikuti oleh adanya sumber daya yang memadai. Sumber daya yang dimaksud dalam konteks ini adalah manusia atau dikenal dengan karyawan (Lina, 2013). Pemberian imbalan kepada karyawan dianggap sebagai salah satu tantangan bagi perusahaan, karena menyangkut kepentingan perusahaan dan karyawan itu sendiri (Cholis, 2013). Sistem penggajian dan pengupahan yang baik diharapkan mampu mengefektifkan dan mengefesiensikan dalam proses pelaksanaan penggajian dan pengupahan, sehingga kendala ataupun permasalahan yang mungkin terjadi dapat diminimalisir.

Mulyadi (2010:373) menyatakan bahwa dalam perusahaan manufaktur, pembayaran kepada karyawan biasanya dibagi menjadi dua golongan: gaji dan upah. Gaji umumnya merupakan pembayaran atas penyerahan jasa yang dilakukan oleh karyawan yang mempunyai jenjang jabatan manajer, sedangkan upah umumnya merupakan pembayaran atas penyerahan jasa yang dilakukan oleh karyawan pelaksana (buruh) (Budriawan, 2008). Umumnya gaji dibayarkan secara tetap per bulan, sedangkan upah dibayarkan berdasarkan hari kerja, jam kerja, atau jumlah satuan produk yang dihasilkan oleh karyawan. Perusahaan manufaktur merupakan perusahaan bisnis di sektor riil yang sangat rentan dan sensitif bila terjadi inflasi (Mardiati 2017). Dengan terjadinya fluktuasi kurs rupiah yang cukup tajam dan ketidakstabilan kurs rupiah dapat menyebabkan kemampuan daya beli masyarakat akan berkurang, bisnis sektor rill adalah bisnis yang bersentuhan langsung dengan permintaan pasar dan kemampuan daya beli lokal (Buchari, 2018).

Perusahaan dalam menjalankan operasionalnya membutuhkan sebuah sistem akuntansi yang baik. Peran sistem akuntansi yang ada pada perusahaan berhubungan erat dengan pengendalian internal perusahaan. Sistem akuntansi yang baik akan tercipta dengan adanya pengendalian internal perusahaan yang baik (Maharani, 2014).

Sistem yang dijadikan topik dalam penelitian ini adalah sistem penggajian yang diterapkan pada CV Lisa Jaya Mandiri Jember. CV Lisa Jaya Mandiri merupakan sebuah perusahaan yang bergerak dalam bidang produksi dan distribusi makanan dan minuman. Sistem penggajian pada CV Lisa Jaya Mandiri Jember masih memiliki kelemahan dalam prosedur pemberian gaji.

Berdasakan hasil observasi awal peneliti yaitu saat wawancara pada CV Lisa Jaya Mandiri terdapat sebuah permasalahan yang terjadi pada pemberian gaji perusahaan. Permasalahan yang terjadi pada CV Lisa Jaya Mandiri Jember yaitu kurangnya fungsi pengendalian terhadap gaji. Kurangnya fungsi pengendalian ini ditandai dengan sering terjadinya kesalahan pada saat pemberian potongan karyawan dan kesalahan input data gaji perusahaan. Sehingga dalam pelaporannya mengalami ketidak tepatan waktu dan harus dilakukan pengecekan ulang terhadap pencatatan data gaji karyawan. Selain itu, pada fungsi gaji juga bertugas melakukan pengawasan terhadap fungsi produksi yang mengakibatkan kerangkapan fungsi pada perusahaan. Kerangkapan fungsi tersebut berakibat pada sistem penggajian karyawan pada perusahaan yang kurang memadai. Sehingga, perlu dilakukan evaluasi terhadap sistem penggajian perusahaan mengingat sistem gaji perusahaan pada CV Lisa Jaya Mandiri Jember masih menggunakan sistem manual.

Berdasarkan uraian uraian permasalahan di atas, maka peneliti dalam upaya melakukan penelitian ini tertarik untuk mengangkat sebuah judul penelitian yaitu sebagai berikut: "Evaluasi Sistem Penggajian pada CV. Lisa Jaya Mandiri Jember".

\section{Metode}

Jenis penelitian dalam penelitian ini adalah penelitian deskriptif dimana peneliti secara langsung mendatangi objek penelitian yaitu CV Lisa Jaya Mandiri Jember untuk memperoleh data-data dan informasi. Basirun (2010:5) penelitian deskriptif adalah salah satu jenis penelitian yang tujuannya untuk menyajikan gambaran cara sistematis dan akurat mengenai fakta, sifat dari hubungan antar fenomena yang diteliti pada suatu perusahaan.

Sumber data penelitian merupakan elemen pokok yang menjadi keputusan dalam pemilihan metode dokumentasi bukti (Cindy, 2013). Sumber data yang menjadi bahan observasi dibedakan menjadi dua yaitu: 1) Data primer, data primer merupakan data yang dikumpulkan oleh peneliti dengan cara 
langsung dari sumbernya, 2) Data Sekunder, data sekunder adalah data yang didapat dengan mempelajari beberapa dokumen perusahaan yang bersangkutan.

Teknik analisis data dimulai dengan mengumpulkan data yang tersedia dari sumber yang diperoleh peneliti dari CV Lisa Jaya Mandiri Jember. Selanjutnya, peneliti mendeskripsikan beberapa konsep praktis berdasarkan pemahaman yang diperoleh secara langsung. Konsep praktis tersebut kemudian dideskipsikan dengan cara membandingkan temuan atau pemahaman atas kenyataan yang terdapat dalam sistem penggajian pada CV Lisa Jaya Mandiri Jember dengan konsep atau teori yang berhubungan dengan sistem tersebut. Adapun analisis data dalam penelitian ini adalah sebagai berikut:

Mengevaluai sistem penggajian yang tediri atas: a) dokumen yang digunakan dalam sistem penggajian dan pengupahan, b) catatan akuntansi yang digunakan dalam sistem penggajian dan pengupahan, c) fungsi yang terkait dalam sistem penggajian dan pengupahan, d) prosedur yang membentuk sistem akuntansi penggajian dan pengupahan.

\section{Hasil dan pembahasan}

\section{Dokumen yang Digunakan dalam Sistem Penggajian pada CV. Lisa Jaya Mandiri}

1. Dokumen Pendukung Perubahan Gaji dan Upah

Dokumen ini dikeluarkan oleh fungsi administrasi yang juga merangkap sebagai fungsi kepegawaian pada CV. Lisa Jaya Mandiri yang bertugas dalam memberikan surat-surat keputusan atas perubahan gaji dan upah kepada karyawan, baik dalam kenaikan pangkat atau berupa kenaikan gaji atau upah yang didasarkan pada surat keputusan direktur keuangan CV. Lisa Jaya Mandiri.

2. Kartu Jam Hadir

Dokumen ini digunakan oleh fungsi pencatat waktu untuk mencatat jam hadir setiap karyawan di perusahaan, fungsi pencatatan ini juga dilakukan oleh satu orang yaitu bagian administrasi. Dokumen tersebut berupa absensi karyawan yang dilakukan setiap jam kerja dan sesudah waktu pulang, yang dilakukan dengan cara tandatangan setiap karyawan yang hadir pada absensi yang sudah disediakan pada CV. Lisa Jaya Mandiri.

3. Daftar Gaji dan Daftar Upah

Dokumen ini dibuat oleh bagian administrasi CV. Lisa Jaya Mandiri yang berisi jumlah gaji dan upah bruto setiap karyawan, dikurangi dengan potongan-potongan berupa utang karyawan, iuran, dan lain sebagainya. Dimana sistem pemotongan gaji dan upah sudah dilaksanakan cukup baik sesuai otorisasi direktur keuangan CV. Lisa Jaya Mandiri.

4. Amplop Gaji dan Upah

Uang gaji yang telah direkap yang dicatat oleh bagian administrasi, selanjutnya akan dibayarkan kepada karyawan dengan menggunakan amplop gaji dan upah. Di halaman muka amplop gaji dan upah setiap karyawan sudah berisikan informasi mengenai nama karyawan, nomor identifikasi karyawan dan jumlah gaji bersih yang diterima karyawan CV. Lisa Jaya Mandiri.

5. Bukti Kas Keluar

Dokumen ini merupakan perintah pengeluaran yang dibuat oleh fungsi administrasi berdasarkan informasi dalam daftar gaji dan upah yang telah dibuat sebelumnya. Bukti kas keluar untuk pembayaran gaji dan upah karyawan ini sudah diotorisasi oleh direktur keuangan.

Catatan Akuntansi Yang Digunakan dalam Sistem Penggajian pada CV. Lisa Jaya Mandiri

1. Jurnal Umum

Dalam pencatatan gaji dan upah jurnal umum digunakan untuk mencatat gaji dan upah yang dilakukan pada bagian pembukuan pada CV. Lisa Jaya Mandiri. Pada CV. Lisa Jaya Mandiri peakaian jurnal umum telah sesuai dengan teori yaitu dimana semua pengeluaran dan pendapatan telah dicatat oleh perusahaan berdasarkan tanggal transaksi yang dilakukan.

\section{Buku Besar}

Buku besar merupakan kumpulan dari akun-akun yang telah dilakukan dan dicatat dalam jurnal umum untuk biaya gaji dan upah, dalam hal ini bagian pembukuan yang melakukan pencatatan terhadap buku besar pada CV. Lisa Jaya Mandiri. Buku besar pada CV. Lisa Jaya Mandiri telah dicatat dengan baik sesuai dengan teori dan telah di pilah dan diterapkan dengan baik.

Fungsi - Fungsi yang Terkait atas Sistem Akuntansi Penggajian pada CV. Lisa Jaya Mandiri.

1. Fungsi Administrasi

Fungsi adminsitrasi pada CV. Lisa Jaya Mandiri yang dijalankan oleh fungsi administrasi yang sekaligus dilakukan oleh 1 orang dalam 1 fungsi,yaitu sebagai pencatat waktu, dan pembuat daftar gaji dan upah. Melalui sub bagian pembukuan ini, bertugas untuk mencatat adanya kewajiban yang timbul serta bertugas dalam pembayaran gaji karyawan CV. Lisa Jaya Mandiri. Jaringan Prosedur dalam Sistem Akuntansi Penggajian pada CV. Lisa Jaya Mandiri. Berdasarkan hasil wawancara serta observasi 
langsung pada objek penelitian, pada CV. Lisa Jaya Mandiri terdapat jaringan prosedur yang membentuk sistem akuntansi penggajian yaitu disajikan berdasarkan hasil wawancara sebagai berikut:

2. Prosedur Pencatatan Waktu.

Prosedur pencatatan waktu hadir ini dilakukan oleh bagian administrasi, seperti absensi yang dilakukan pada CV. Lisa Jaya Mandiri. Prosedur pencatatan waktu ini dilakukan oleh karyawan tidak tetap, sedangkan untuk karyawan tetap juga melakukan presesnsi tapi tidak mempengaruhi besarnya pemberian gaji dan upah. Akan tetapi berdasarkan kebijakan pimpinan perusahaan CV. Lisa Jaya Mandiri otorisasi atau persetujuan dilakukan secara bersama-sama.

3. Prosedur Pembuat Daftar Gaji dan Upah.

Dalam prosedur ini, pembuat daftar gaji dan upah membuat daftar gaji dan upah.Bagi karyawan tetap mengalami perubahan gaji dan upah apabila mengalami perubahan kenaikan tingkat jabatan, golongan, dan keluarganya bertambah.Sedangkan untuk karyawan tiadak tetap daftar upah disesuaikan dengan jumlah hari kerjanya.

4. Prosedur Pembuatan Bukti Kas Keluar.

Prosedur ini melibatkan fungsi pembukuan atau keuangan, setelah membuat daftar gaji dan upah selesai kemudian fungsi keuangan membuat bukti kas keluar untuk pembayaran gaji dan upah, setelahnya bukti kas keluar tersebut diserahkan pada bagian bendahara yang sekaligus fungsi administrasi melakukan pembayaran gaji dan upah pada karyawan CV. Lisa Jaya Mandiri.

5. Prosedur Pembayaran Gaji dan Upah.

Prosedur ini melibatkan fungsi administrasi dimana fungsi administrasi tersebut juga melakukan pembayaran yang merangkap jadi fungsi bendahara setelah kas keluar diotorisasi, fungsi administrasi/bendahara mengeluarkan bukti kas keluar.Untuk itu, gaji dapat di ambil di bagian bendahara atau kasir perusahaan.

Evaluasi Sistem Pengendalian Internal yang Berkaitan dengan Sistem Penggajian pada CV. Lisa Jaya Mandiri. Berdasarkan dari hasil penjabaran sekaligus analisis peneliti dan wawancara pada CV. Lisa Jaya Mandiri dan beserta bukti-bukti yang akan dilampirkan nantinya, selanjutnya peneliti dalam tahapan akhir ini akan memberikan evaluasi dan penilaian terhadap sistem pengendalian internal atas gaji dan upah pada CV. Lisa Jaya Mandiri, yaitu sebagai berikut:

1. Aspek Organisasi.

Struktur organisasi yang baik dalam perusahaan adalah struktur organisasi yang memisahkan tugas dan tanggungjawab dari setiap bagian organisasi. Pemisahan tugas yang jelas pada masing-masing bagian akan mempermudah pekerjaan, sehingga karyawan dapat bekerja sesuai dengan kedudukannya (Mulyadi ; 2008). Aspek oganisasi pada CV. Lisa Jaya Mandiri dimulai dari visi misi kemudian struktur organisasi dalam perusahaan tersebut, jika dilihat dari pemisahan tugas dan wewenang yang dilaksanakan oleh CV. Lisa Jaya Mandiri berdasarkan perbandingan dengan teori dan hasil observasi serta wawancara peneliti perlu diadakan evaluasi dan penambahan dokumen KPK. Pemisahan tanggungjawab dan wewenang pada CV. Lisa Jaya Mandiri pada bagian penggajian dan pengupahan dilakukan oleh satu orang yaitu bagian administrasi. Sehingga dengan tidak adanya pemisahan tugas dan wewenang tersebut, CV. Lisa Jaya Mandiri menuai beberapa kesalahan yaitu kesalahan pencatatan atau input data pada pemberian potongan gaji karyawan. Permasalahan yang terjadi pada CV. Lisa Jaya Mandiri ini dapat merugikan karyawan, misalkan kerugian yang berakibat pada karyawan yaitu yang kurang rinci dalam pemberian potongan pada karyawan. Sehingga mengakibatkan karyawan protes karena potongan gaji dirasa terlalu besar dari periode sebelumnya, sehingga gaji karyawan yang didapat tidak sesuai semestinya tanpa disadari oleh bagian administrasi tersebut. Faktor lain yang membuat adanya kesalahan tersebut tidak adanya kartu potongan gaji dan upah pada CV. Lisa Jaya Mandiri sehingga perlu ditambahkan dokumen terkait tersebut, demi efektifitasnya pemberian gaji dan upah karyawan pada CV. Lisa Jaya Mandiri. Untuk itu, perlu di adakan evaluasi kembali terhadap pengendalian internal atas gaji dan upah karyawan CV. Lisa Jaya mandiri Jember.

2. Aspek Sistem Otorisasi.

Dari segi aspek otorisasi dari CV. Lisa Jaya Mandiri sudah memadai dan sesuai dengan unsur-unsur pengendalian internal menurut teori Mulyadi (2008), yaitu sudah ada kejelasan dalam sistem wewenang dan otorisasi, yaitu sebagai berikut : a) Setiap dokumen gaji dan upah yang lengkap akan diotorisasi langsung oleh pimpinan CV. Lisa Jaya Mandiri, b) Perintah lembur harus diotorisasi oleh kepala departemen karyawan yang bersangkutan, pada CV. Lisa Jaya Mandiri otorisasi ini dilaksanakan oleh pegawai bagian administrasi perusahaan. 
3. Aspek Prosedur Pencatatan.

Dalam aspek prosedur pencatatan dalam CV. Lisa Jaya Mandiri berdasarkan analisa peneliti sudah memenuhi kriteria dari unsur-unsur sistem pengendalian internal menurut Mulyadi (2008), di dalam prosedur pencatatan perusahaan sudah melakukan prosedur secara lengkap mulai dari pembuatan daftar hadir sampai pada pembayaran gaji pada karyawan CV. Lisa Jaya Mandiri, serta ada kejelasan mengenai perubahan data pegawai dengan daftar gaji dan upah. Akan tetapi, kelemahan yang terjadi pada perusahaan terlihat pada pemisahan tugas dan wewenang karyawan yang masih diakukan oleh satu orang yang mengakibatkan kesalahan dalam pencatatan input data serta ketidaktepatan waktu pelaporan gaji dan upah pada CV. Lisa Jaya Mandiri Jember. Selain itu, dokumen dalam alur prosedur pencatatan pada CV. Lisa Jaya Mandiri hendaknya ditambahkan dengan Kartu Penghasilan Karyawan (KPK) untuk lebih meningkatkan keefektifan pelaporan serta meminimalisir kesalahan yang terjadi.

4. Aspek Praktik yang Sehat.

Dari segi aspek praktik yang sehat, pada CV. Lisa Jaya Mandiri ini masih belum sesuai dengan unsurunsur pengendalian internal yang tertera pada teori Mulyadi (2008) dan juga perlu adanya pembenahan kembali agar dapat meminimalisir permasalahan pada perusahaan dan dapat mempercepat input pemasukan data pada saat pembukuan yang dilakukan oleh bagian administrasi, yaitu sebagai berikut : a) Mengenai Mengenai kartu jam hadir, pada CV. Lisa Jaya Mandiri sudah memakai kartu jam hadir, akan tetapi kartu jam kerja tidak dapat dibandingkan sesuai dengan teori Mulyadi (2008), karena kartu jam hadir akan dibandingkan dengan kartu jam kerja yang akan dipakai sebagai dasar distribusi biaya tenaga kerja langsung, dan kartu jam hadir tersebut nantinya dijadikan satu dengan absensi karyawan yang berupa rekap kartu jam hadir karyawan, b) Mengenai pemisahan tugas dan wewenang yang dilakukan dan dilaksanakan pada perusahaan juga masih butuh peningkatan dan pembenahan kembali, terutama pada fungsi administrasi/pembukuan dalam hal pemasukan data karyawan dan pembuatan gaji dan upah karyawan, c) Mengenai dokumen terkait pada CV. Lisa Jaya Mandiri yaitu kartu penghasilan karyawan (KPK) yang berisi pemberian potongan dan juga gaji dan upah karyawan, d) Masih minimnya penggunaan sistem terkomputerisasi dan hanya beberapa, seperti absensi otomatis pun belum digunakan, sehingga masih menggunakan absensi manual.

\section{Simpulan dan saran}

Berdasarkan hasil penelitian yang dilakukan dan hasil analisa sekaligus membandingkan dengan teori sistem pengendalian internal atas gaji dan upah, peneliti menuliskan kesimpulan sebagai tahap akhir dalam penilitian ini. Kesimpulan ini diharapkan dapat berguna dalam meringkas dan memberikan gambaran terhadap permasalahan dan hasil evaluasi pembahasaan yang telah dilakukan. Selain itu, pada langkah selanjutnya peneliti mencoba memberikan saran untuk perusahaan dan bagi pihak lain yang diharapkan dapat bermanfaat dan berguna dalam penelitiaan selanjutnya, adapun kesimpulan dan saran yang dilakukan peneliti yaitu sebagai berikut:

1. Dilihat dari sistem penggajian pada CV. Lisa Jaya Mandiri sudah melakukan prosedur dengan baik, akan tetapi masih perlu di evaluasi dari segi dokumen terkait yaitu Kartu Penghasilan Kayawan perlu ditambahkan. Penambahan dokumen kartu penghasilan karyawan ini berguna dalam merinci potongan gaji karyawan agar meminimalisir kesalahan yang terjadi dalam pencatatan pemberian potongan gaji karyawan. Sehingga secara keseluruhan dapat disimpulkan penerapan sistem penggajian pada CV. Lisa Jaya Mandiri sudah diterapkan dengan perlu diadakan beberapa evaluasi terkait dokumen penggajian karyawan dan pemisahan tugas yang jelas dari bagian administrasi.

2. Dilihat dari sistem penggajian yang diterapkan pada CV. Lisa Jaya Mandiri berdasarkan informasi serta lampiran dan data-data yang didapatkan oleh peneliti, maka sistem penggajian pada CV. Lisa Jaya Mandiri perlu diadakan evaluasi kembali untuk meminimalisir permasalahan yang terjadi serta meningkatkan kinerja perusahaan lebih baik lagi dimasa mendatang.

Berdasarkan kesimpulan yang diperoleh, maka dapat di ajukan saran yaitu sebagai berikut hendaknya sistem pengggajian dievaluasi kembali terutama dalam hal pemisahan tugas dan wewenang serta dokumen terkait yaitu kartu penghasilan karyawan yang perlu ditambahkan, hal ini dilakukan dalam upaya meminimalisir permasalahan kesalahan pencatatan pemberian potongan pada CV. Lisa Jaya Mandiri. Untuk peneliti selanjutnya dalam melakukan penelitian bukan hanya dalam segi pengendalian internal atas gaji dan upah, melainkan dari sistem pengendalian internal perusahaan lainnya serta lebih melengkapi dari lampiran-lampiran terkait sistem pengendalian internal atas gaji dan upah serta buktibukti terkait lainnya pada perusahaan. 


\section{Daftar Rujukan}

Baridwan, Zaki. 2008. Sistem Akuntansi Penyusunan Prosedur dan Metode. BPFE, Yogyakarta.

Basirun, Abdul. 2010. Jenis-jenis Penelitian. Gombong, Jawa Tengah.

Buchari,E. Satiaputra. 2018. Analisis Kinerja Keuangan Perusahaan Manufaktur Serta Pengaruhnya Terhadap Harga Saham (Sebuah Studi Empiris Pada Perusahaan manufaktur Industri logam go public di BEI). JIMF (Jurnal Ilmiah Manajemen Forkamma), Vol.1, No.4.

Cholis Hidayat. 2013. Analisis Pengaruh Kinerja Keuangan Terhadap Return Saham Dan Kapitalisasi Pasar Perusahaan Manufaktur Yang Terdaftar Di BEI. Dalam Jurnal Media Mahardhika Vol.11 No.3 Mei 2013.

Christianti Ari. 2013. Akurasi Prediksi Financial Distress: Perbandingan Model Altman Dan Ohlson. Dalam Jurnal Ekonomi dan Bisnis. Vol.7, No.2, Juli 2013. ISSN 1978-3116.

Cindy Halim,2013, "Pengaruh Variabel Makroekonomi Terhadap Kinerja Perusahaan Di Indonesia Pasca Merger dan Akuisisi. Dalam Jurnal Finesta Vo.1, No.2, 2013: 24-29

Linna Ismawati, Beni Hermawan.2013" Pengaruh Kurs Mata Uang Rupiah Atas Dolar AS, Tingkat Suku Bunga Sertifikat Bank Indonesia Dan Tingkat Inflasi Terhadap Indeks Harga Saham Gabungan (IHSG) Pada Bursa Efek Indonesia". Dalam Jurnal Ekono Insentif Kopwil4, Volume 7 No.2, Oktober 2013. ISSN:1907-0640, halaman 1 s.d 13

Mulyadi. 2008. Sistem Akuntansi. Edisi 3. Jakarta: Salemba Empat.

Mulyadi. 2010. Akuntansi Biaya. Edisi Kelima. Cetakan Kesembilan. UPP-STIM YKPN, Yogyakarta.

Mardiyati, U., Ahmad, G., \& Putri, R. 2017. Pengaruh Kebijakan Dividen, Kebijakan Hutang Dan Profitabilitas Terhadap Nilai Perusahaan Manufaktur Yang Terdaftar Di Bursa Efek Indonesia (BEI) Periode 2005-2010. JRMSI - Jurnal Riset Manajemen Sains Indonesia, Volume 3, Nomor 1.

Maharani, I Gusti Ayu Cahya; Suardana, Ketut Alit. 2014. Pengaruh Corporate Governance, Profitabilitas, Dan Karakteristik Eksekutif Pada Tax Avoidance Perusahaan Manufaktur. E-Jurnal Akuntansi, Volume 9, Nomor 2.

Purnomo Herry. 2010. Dasar-dasar Perpajakan dan Akuntansi Pajak. Erlangga, Jakarta.

Rahayu Siti Kurnia dan Eli Suhayati. 2009. Auditing Konsep Dasar dan Pedoman Pemeriksaan Akuntan Publik. Graha Ilmu, Bandung.

Riahi, Ahmad dan Belkoui. 2000. Teori Akuntansi. Edisi Pertama. Jakarta: Salemba Empat.

Soemarso S.R., 2009. Akuntansi Suatu Pengantar. Edisi Kelima (Revisi), Salemba Empat, Jakarta.

Soeratno, Lincoln. 2010. Metodologi Penelitian Untuk Ekonomi dan Bisnis. Edisi Revisi. UPP STIM YKPN, Yogyakarta. 